Article

\title{
Antibacterial Effect of the Natural Polymer $\varepsilon$-Polylysine Against Oral Pathogens Associated with Periodontitis and Caries
}

\author{
Shinechimeg Dima ${ }^{1,+} \mathbb{C}$, Yin-Yin Lee ${ }^{1}$, Ikki Watanabe ${ }^{2}$, Wei-Jen Chang ${ }^{1,3,4,+}{ }^{,}$, Yu-Hua Pan ${ }^{1,5,6,7}$ and \\ Nai-Chia Teng $1,4,8, *$ \\ 1 School of Dentistry, College of Oral Medicine, Taipei Medical University, $250 \mathrm{Wu}$-Hsing Street, \\ Taipei 110, Taiwan; shinechimeg.dima@gmail.com (S.D.); innate19@hotmail.com (Y.-Y.L.); \\ cweijen1@tmu.edu.tw (W.-J.C.); shalom.dc@msa.hinet.net (Y.-H.P.) \\ 2 Gerodontology and Oral Rehabilitation, Graduate School of Medical and Dental Sciences, Tokyo Medical and \\ Dental University, Tokyo 113-8510, Japan; ikki.ore@tmd.ac.jp \\ 3 Department of Dentistry, Shuang Ho Hospital, New Taipei 23561, Taiwan \\ 4 Department of Dentistry, Taipei Medical University Hospital, 250 Wu-Hsing Street, Taipei 110, Taiwan \\ 5 Department of Dentistry, Chang Gung Memorial Hospital, Taipei 106, Taiwan \\ 6 Graduate Institute of Dental \& Craniofacial Science, Chang Gung University, Taoyuan 333, Taiwan \\ 7 School of Dentistry, College of Medicine, China Medical University, Taichung 404, Taiwan \\ 8 Dental Department, Taipei Medical University Hospital, Taipei 110, Taiwan \\ * Correspondence: dianaten@tmu.edu.tw \\ + These authors contributed equally to this work.
}

Received: 3 April 2020; Accepted: 25 May 2020; Published: 27 May 2020

\begin{abstract}
Antimicrobials are important adjuncts in the treatment of caries and periodontitis. However, increased bacterial resistance and hypersensitivity reactions to commonly used antimicrobials have led to an increasing demand for safe and natural substances. The objective of this study was to investigate the antibacterial effects of $\varepsilon$-polylysine against oral pathogens Streptococcus mutans and Porphyromonas gingivalis. Broth dilution assay, scanning electron microscopy (SEM) and confocal laser scanning microscopy (CLSM) analyses were performed to explore the antibacterial effect of $\varepsilon$-polylysine against S. mutans strain ATCC25175 and P. gingivalis strain ATCC332277. For the test solution, $\varepsilon$-polylysine was added to the bacterial suspension to prepare $0.125 \%, 0.25 \%, 0.5 \%$ and $1 \% \varepsilon$-polylysine solutions diluted in broth medium. All four concentrations demonstrated complete inhibition of S. mutans and significantly reduced viable cell counts of $P$. gingivalis after $24 \mathrm{~h}$. From starting inoculum of $9.15 \log \mathrm{CFU} / \mathrm{mL}$, $P$. gingivalis cell counts reduced to $4.01 \log \mathrm{CFU} / \mathrm{mL}$ in the $0.125 \% \varepsilon$-polylysine treatment group. SEM, CLSM, and the LIVE/DEAD bacterial assay of $\varepsilon$-polylysine application on $P$. gingivalis biofilm-dentin specimens revealed bacterial cell membrane disruption and irregular cell morphologies. The results indicated satisfactory antibacterial efficacy of $\varepsilon$-polylysine against $P$. gingivalis and S. mutans in liquid medium and as an application on biofilm-dentin specimens.
\end{abstract}

Keywords: polylysine; antibacterial; polypeptide

\section{Introduction}

Oral biofilms are three dimensional, dynamic microbial communities growing on the solid surfaces of teeth [1]. Dental caries and periodontitis are infectious diseases of the oral cavity, and oral biofilms are 
strongly associated with its etiology [2]. Dental caries is a hard tissue disease that involves acidogenic plaque bacteria, including Streptococcus mutans, Streptococcus sobrinus, and Lactobacillus spp. [3], residing primarily in the supragingival plaque. Periodontitis is a common chronic inflammatory disease caused by an accumulation of different pathogenic biofilm-forming bacteria in subgingival plaque, leading to an exaggerated immune response that destroys periodontal ligament and causes alveolar bone loss. Porphyromonas gingivalis, Tannerella forsythia, and Treponema denticola are considered to be the major pathogens involved in advancing periodontitis [3,4].

The prevention and treatment of caries and periodontitis aim to control plaque biofilms using numerous antimicrobial agents, which are formulated into oral health care products. Fluoride remains the cornerstone treatment for caries prevention; however, additional antiplaque approaches are required to enhance its effectiveness. Concurrent use of chemical substances and mechanical cleaning has been demonstrated to be beneficial in decreasing biofilm formation in periodontitis treatment. A broad-spectrum antimicrobial agent commonly used for the antiplaque approach in both caries and periodontitis treatments is chlorhexidine. Studies, however, have demonstrated increasing severe hypersensitivity reactions $[5,6]$ and antibiotic resistance to chlorhexidine [7,8]. Although several antimicrobials, such as azithromycin [9], minocycline [10], tetracycline, and metronidazole [11], demonstrated larger improvements in periodontal health when used as local deliveries in adjunct to scaling and root planning, compared with scaling and root planning alone, adverse effects such as periodontal bacterial resistance to such antimicrobial agents have been reported [12-14]. The challenges caused by drug-resistant bacteria have created a need for the development of effective and safe antimicrobial compounds [15]. Ideal antibacterial compounds must be effective against a wide range of microorganisms, act rapidly, maintain activity at low concentrations, have no side effects, and be usable without discomfort.

In the past three decades, antimicrobial peptides have been researched extensively because of their antimicrobial ability and the low risk of developing bacterial resistance. $\varepsilon$-Polylysine is a cationic, naturally occurring polypeptide that is produced as extracellular material by Streptomyces albulus [16]. It was first identified by Shime and Sakai in the 1970s [17] and is produced industrially through the fermentation of Streptomyces albulus mutated strains for use as a food preservative. $\varepsilon$-Polylysine is generally regarded as a safe (GRAS) natural polypeptide consisting of L-lysine units $(n=25-30)$ [18] that is biodegradable, water-soluble, nontoxic, and edible. The antibacterial characteristics of $\varepsilon$-polylysine is well established in food industry and it is increasingly being applied in biomedicine in recent years [19-22]. Few studies have utilized $\varepsilon$-polylysine for dental application purposes, including composite [23,24], dental adhesive [25], implant surface modification [26] and antimicrobials [27,28]. However, the effect of $\varepsilon$-polylysine on P. gingivalis is less studied and the investigating methods of its antibacterial effectiveness against oral microorganisms were limited primarily to inhibition of planktonic bacterial growth. In addition, the demand for research on further applications of $\varepsilon$-polylysine in dental practice is increasing. Therefore, the objective of this study was to investigate the antibacterial effects of $\varepsilon$-polylysine ( $\varepsilon$-PL) against $S$. mutans and $P$. gingivalis in planktonic growth and biofilm on the dentin surface.

\section{Materials and Methods}

\subsection{Bacterial Strains, Growth Conditions, Culture Media, and Antimicrobial Preparation}

S. mutans strain ATCC25175 was cultured in Tryptic soya broth and grown in Tryptic soya agar (Thermo Fischer Scientific, Waltham, MA, USA) in an anaerobic chamber with an atmosphere of $85 \% \mathrm{~N}_{2}$, $5 \% \mathrm{H}_{2}$, and $10 \% \mathrm{CO}_{2}$ for 2 days. A stock culture of P. gingivalis ATCC332277 was cultured in brain heart infusion (BHI) broth (Difco Laboratories Inc., Detroit, MI, USA) supplemented with $0.5 \mathrm{mg} / \mathrm{mL}$ hemin, $0.1 \mathrm{~g} / \mathrm{mL}$ vitamin $\mathrm{K}$, and $0.4 \mathrm{~g} / \mathrm{mL}$ L-cysteine and used for the experiments after being assessed using gram staining. P. gingivalis stocks were grown in $\mathrm{BHI}$ agar containing $5 \%$ defibrinated sheep 
blood, $0.5 \mathrm{mg} / \mathrm{mL}$ hemin, $0.1 \mathrm{~g} / \mathrm{mL}$ vitamin $\mathrm{K}$, and $0.4 \mathrm{~g} / \mathrm{mL}$ L-cysteine in an anaerobic chamber with an atmosphere of $85 \% \mathrm{~N}_{2}, 5 \% \mathrm{H}_{2}$, and $10 \% \mathrm{CO}_{2}$ for 2 days. The culture temperature was maintained at $37^{\circ} \mathrm{C}$ for each strain. Aliquots were stored at $-70{ }^{\circ} \mathrm{C}$.

\subsection{Broth Dilution Assay}

The inhibitory effect of $\varepsilon$-polylysine against $S$. mutans and $P$. gingivalis was assessed using broth dilution assay. The initial bacterial suspension was prepared at an optical density of 0.1 using spectrophotometer (GENESYS 10S UV-Vis, Thermo Fischer Scientific, Waltham, MA, USA). The test solution, $\varepsilon$-polylysine, was added as the bacterial suspension to obtain $\varepsilon$-polylysine concentrations of $0.125 \%, 0.25 \%, 0.5 \%$, and $1 \%$ in the broth medium. The bacterial suspension was incubated at $37{ }^{\circ} \mathrm{C}$ in anaerobic conditions. At 1, 6, 12, and $24 \mathrm{~h}, 100 \mu \mathrm{L}$ of bacterial suspension was collected for the broth dilution assay. A serial dilution in phosphate-buffered saline (PBS) $\left(10^{1}-10^{4}\right)$ was performed. Subsequently, 25 to $100 \mu \mathrm{L}$ of bacterial suspension was inoculated on agar plates. The plates were incubated at $37^{\circ} \mathrm{C}$ in an anaerobic chamber with an atmosphere of $85 \% \mathrm{~N}_{2}, 5 \% \mathrm{H}_{2}$, and $10 \% \mathrm{CO}_{2}$ for $48 \mathrm{~h}$, and colony-forming units $(\mathrm{CFU} / \mathrm{mL})$ were counted. Three independent experiments were performed and the mean measurements were assessed.

\subsection{SEM Observations on Bacterial Biofilms}

Recently extracted, caries-free, non-restored human third molar teeth were cleansed and stored in $0.1 \%$ thymol until use. The crowns were sectioned through cutting with a low-speed water-cooled diamond saw (Isomet; Buehler, Lake Bluff, IL, USA). The teeth were then cut along the buccolingual plane to obtain the cervical dentin for dentin specimen $\left(4 \times 4 \times 1 \mathrm{~mm}^{3}\right)$ preparation. The cementum was removed and the surfaces of each dentin disc were polished with 600-grit and 1000-grit silicon carbide paper under running water for $30 \mathrm{~s}$ each. The dentin disks were then rinsed with $1 \mathrm{M}$ acetic acid for $30 \mathrm{~s}$ to remove the smear layer and expose dentinal tubules, rinsed with distilled water for $30 \mathrm{~s}$, and then autoclaved $\left(121^{\circ} \mathrm{C}\right.$ for $20 \mathrm{~min}$ ). The specimens were then aseptically placed in sterile 24-well plates (Costar, Corning Life Sciences, Tewksbury, MA, USA) with the dentin side positioned upwards. A 200- $\mu \mathrm{L}$ P. gingivalis (ATCC 33277) bacterial suspension (approximately $10^{6}$ bacteria) containing $1.8 \mathrm{~mL}$ of BHI media supplemented with $0.1 \mathrm{~g} / \mathrm{mL}$ vitamin $\mathrm{K}, 0.5 \mathrm{mg} / \mathrm{mL}$ hemin, and $0.4 \mathrm{~g} / \mathrm{mL}$ L-cysteine was added to each well. The plates were incubated in anaerobic jars $\left(37^{\circ} \mathrm{C}\right)$ for 7 days to enable biofilm formation. The broth was changed every 2 days. All the specimens were then rinsed for $1 \mathrm{~min}(2 \times)$ in PBS (Sigma-Aldrich, St. Louis, MO, USA) to remove nonadherent bacterial cells before treatment. Biofilm-infected dentin specimens were randomly divided into five groups: negative controls (no treatment) and groups treated with $\varepsilon$-polylysine solutions at concentrations of $0.125 \%, 0.25 \%, 0.5 \%$, and $1 \%$. Four concentrations of $\varepsilon$-polylysine solutions were applied to the biofilm-dentin specimens using a microbrush. The dentin specimens were harvested, fixed, and mounted on aluminium stubs, before being sputter-coated with $\mathrm{Au}-\mathrm{Pd}$. Scanning electron microscopy (SU-3500, Hitachi, Tokyo, Japan) was then performed to assess biofilm inhibition.

\subsection{CLSM Analysis of Biofilm Inhibition}

The LIVE/DEAD BacLight bacterial viability kit (Thermo Fisher Scientific, Waltham, MA, USA) was used to assess the antibacterial effect of $\varepsilon$-polylysine against P. gingivalis; $3 \mu \mathrm{L}$ of each dye, SYTO 9 and propidium iodide, were added to $1 \mathrm{~mL}$ of distilled water to prepare the working solution. From the working solution, $200 \mu \mathrm{L}$ was added to each of the control and treated dentin samples. The samples were incubated for $20 \mathrm{~min}$ at room temperature in a dark environment before confocal laser scanning microscopy (CLSM) analysis was conducted. The bacterial cells were imaged using a confocal laser microscope (Leica TCS SP5, Leica Microsystems, Wetzlar, Germany) with appropriate filters. 


\subsection{Statistical Analysis}

Quantitative data are reported as means \pm standard deviations. The antibacterial efficacy of $\varepsilon$-polylysine was assessed based on the viable cell count $(\log \mathrm{CFU} / \mathrm{mL})$ after $\varepsilon$-polylysine treatment. Analyses of variance and Mann-Whitney tests were used to determine whether significant differences existed in terms of $\log \mathrm{CFU} / \mathrm{mL}$ between groups. A $p$-value of $<0.05$ was considered to be statistically significant.

\section{Results}

\subsection{Antimicrobial Activity}

Representative results from three independent experiments are displayed in Figures 1 and 2. A dose-dependent response was identified in the inhibitory effect of $\varepsilon$-polylysine on $S$. mutans growth after 6 and $12 \mathrm{~h}$. With a starting inoculum of $8.86 \log \mathrm{CFU} / \mathrm{mL}, 0.5 \%$ and $1 \% \varepsilon$-polylysine eliminated recoverable CFUs of $S$. mutans after $12 \mathrm{~h}$ (Figure 1). The viable cell counts of $S$. mutans in the $0.125 \% \varepsilon$-polylysine group were $5.28 \pm 0.88$ and $1.5 \pm 1.23 \log \mathrm{CFU} / \mathrm{ml}$ after 6 and $12 \mathrm{~h}$ of incubation, respectively. The $0.25 \%$ $\varepsilon$-polylysine group demonstrated viable $S$. mutans cell counts of $3.07 \pm 0.13$ and $1.19 \pm 1.22 \mathrm{log} \mathrm{CFU} / \mathrm{ml}$ after 6 and $12 \mathrm{~h}$, respectively. All four concentrations demonstrated complete inhibition against $S$. mutans after $24 \mathrm{~h}$.

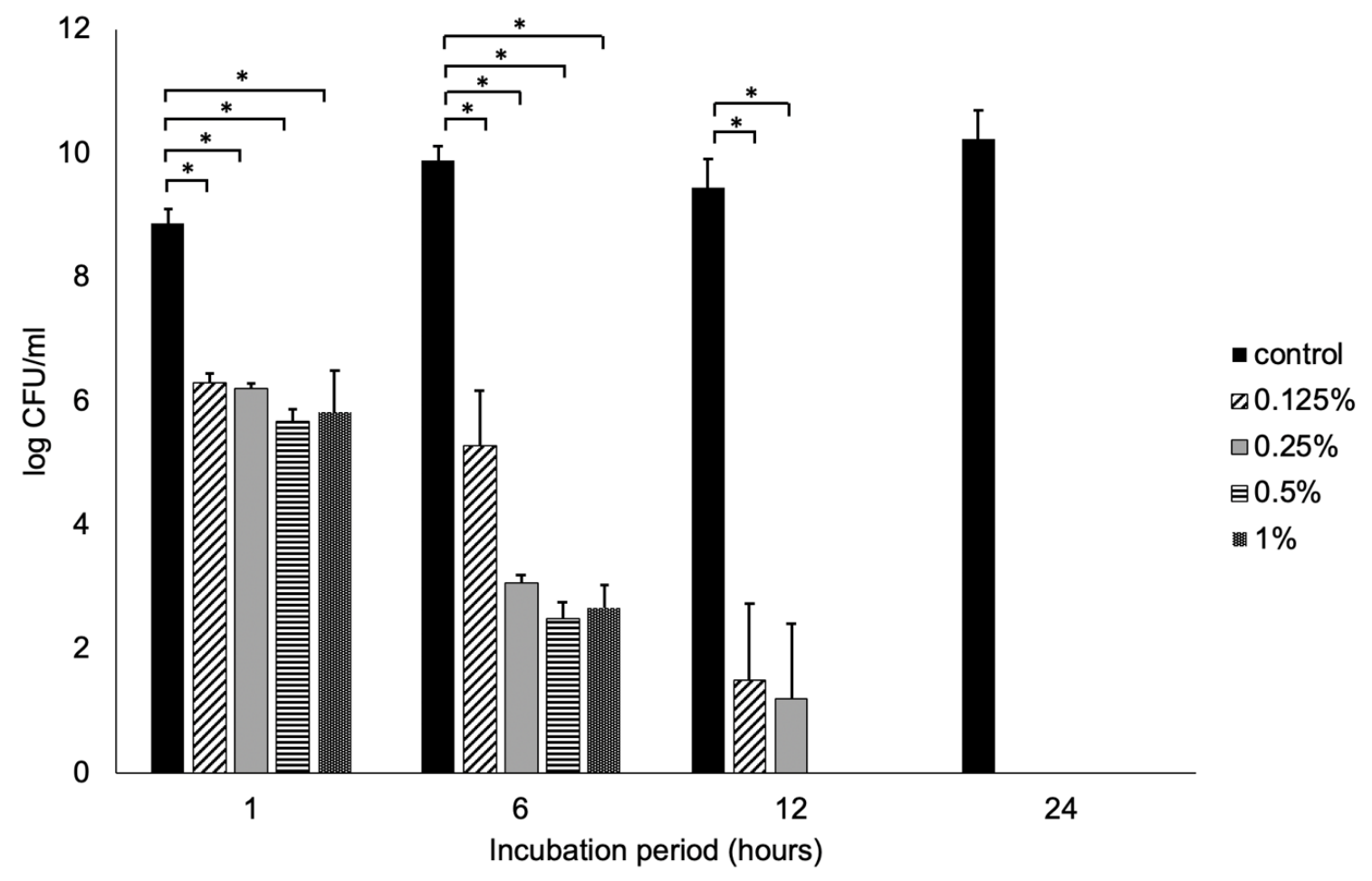

Figure 1. S. mutans bacterial viability measured as colony-forming units (CFUs) on a log scale after $0.125 \%$, $0.25 \%, 0.5 \%$, and $1 \% \varepsilon$-polylysine treatments for $1,6,12$, and $24 \mathrm{~h}$. All values depicted are the means of triplicate measurements. * Statistical significance at $p<0.05$ by ANOVA test. 


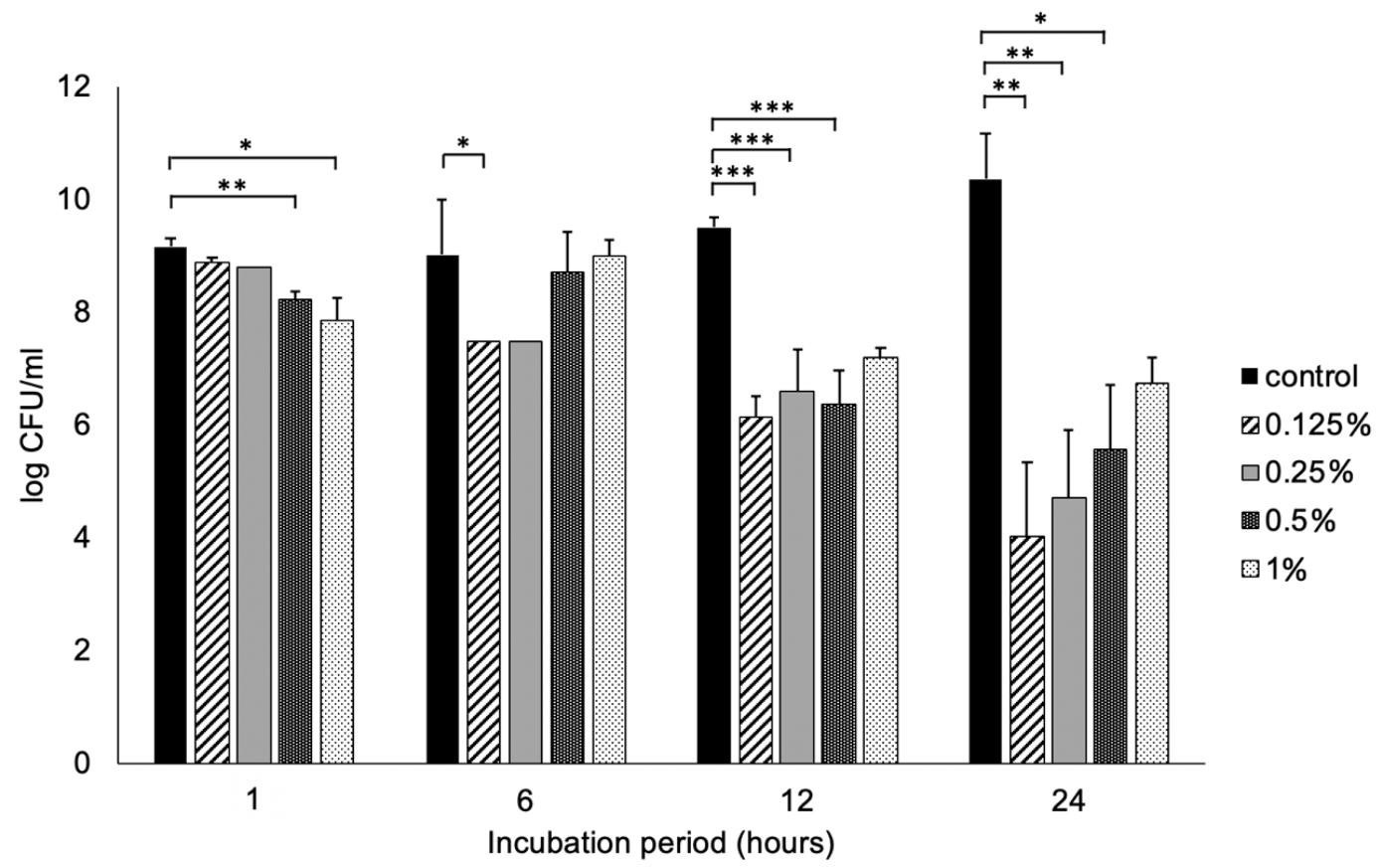

Figure 2. $P$. gingivalis bacterial viability measured as colony-forming units (CFU) on a log scale after $0.125 \%$, $0.25 \%, 0.5 \%$, and $1 \% \varepsilon$-polylysine treatments for $0,6,12$, and $24 \mathrm{~h}$. All values depicted are the means of triplicate measurements. Statistical significance at ${ }^{*} p<0.05,{ }^{* *} p<0.01,{ }^{* *} p<0.001$ by Mann-Whitney test.

The starting inoculum of $P$. gingivalis was $9.15 \log \mathrm{CFU} / \mathrm{ml}$ and $\varepsilon$-polylysine reduced the viability of P. gingivalis in a time-dependent manner. The relative viability of $\varepsilon$-polylysine-treated cells was greater in the $1 \%$ e-polylysine group than in the other three groups; the difference became more distinct after $24 \mathrm{~h}$. Among all four treatment groups, the minimum viable $P$. gingivalis cell count was observed in $0.125 \%$ $\varepsilon$-polylysine group at all periods after $6 \mathrm{~h}$. In $0.125 \% \varepsilon$-polylysine treated samples, the $P$. gingivalis cell count was $6.12 \pm 0.37$ at $12 \mathrm{~h}$ which further reduced to $4.01 \pm 1.31 \log \mathrm{CFU} / \mathrm{ml}$ after $24 \mathrm{~h}$ of incubation. In contrast, the recoverable CFUs of $P$. gingivalis after $24 \mathrm{~h}$ of incubation was $4.69 \pm 1.2,5.56 \pm 1.14$ and $6.73 \pm 0.45 \log \mathrm{CFU} / \mathrm{ml}$ in $0.25 \%, 0.5 \%$, and $1 \% \varepsilon$-polylysine groups, respectively.

\subsection{Inhibitory Effect on Biofilm}

The SEM results obtained after the application of four concentrations of $\varepsilon$-polylysine on $P$. gingivalis biofilm-dentin disks revealed a reduced number of $P$. gingivalis bacterial cells in all four groups compared with the control group. SEM images revealed significant morphological changes in the P. gingivalis cells treated with $\varepsilon$-polylysine. The untreated cells appeared to be regular spherical shapes with smooth surfaces and intact cell walls and membranes. The SEM images of the biofilm-dentin specimens after they were exposed to $\varepsilon$-polylysine application revealed that $P$. gingivalis bacterial cells exhibited membrane disruption and irregular cell morphology compared with untreated cells (Figure 3).

A CLSM experiment was performed to qualitatively assess the antibacterial effect of $\varepsilon$-polylysine on the $P$. gingivalis biofilm-dentin surface. The results of LIVE/DEAD bacterial staining assay after 7 days of $\varepsilon$-polylysine treatment on the $P$. gingivalis biofilm-dentin discs showed green and red stained bacterial cells in the control group. The $0.125 \% \varepsilon$-polylysine treatment group had completely dead cells stained red. The $0.25 \%$ and $0.5 \% \varepsilon$-polylysine groups presented a reduced number of live and dead bacterial cells compared with the control group. The $1 \% \varepsilon$-polylysine group had more live cells compared than the other three experimental groups (Figure 4). 


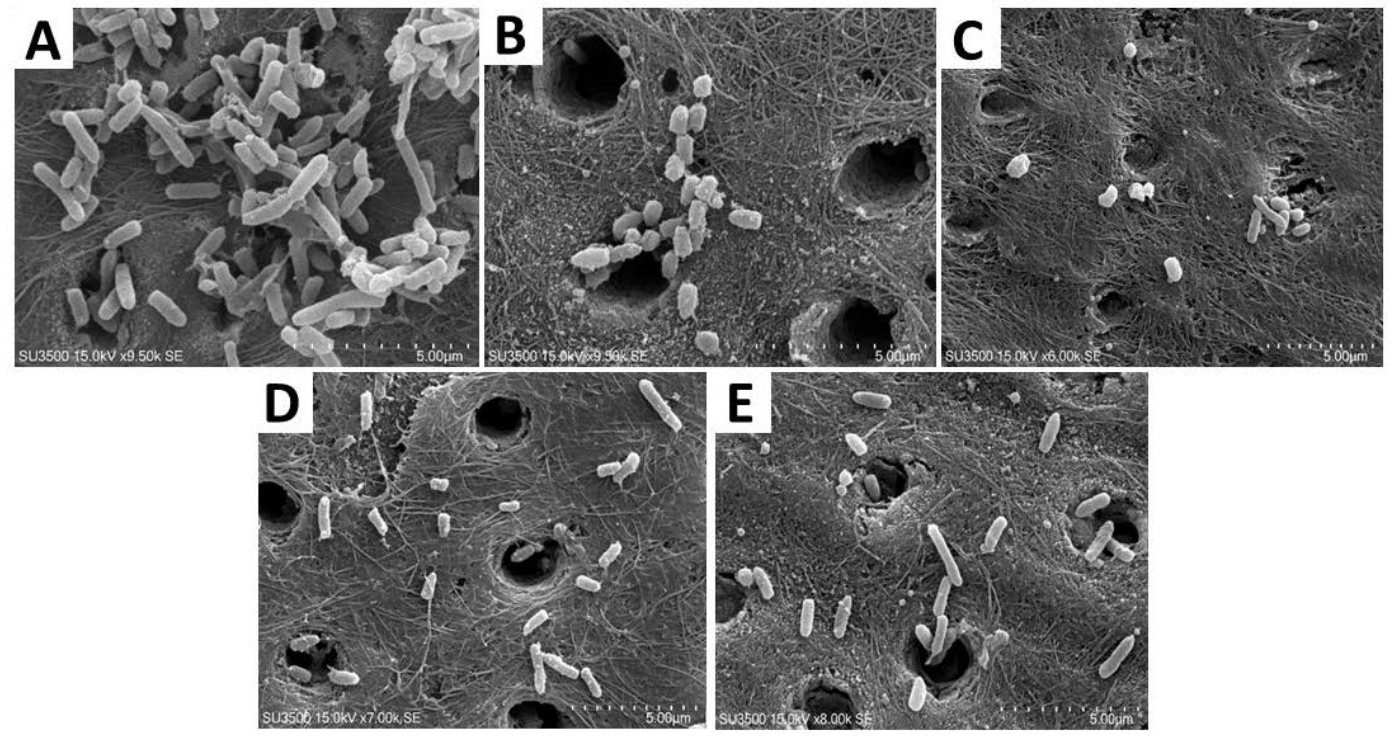

Figure 3. SEM images of $P$. gingivalis biofilm-dentin specimens (on day 7) after the application of different concentrations of $\varepsilon$-polylysine (5 $\mu \mathrm{m}$ ). (A) control; (B) $0.125 \% \varepsilon$-PL; (C) $0.25 \% \varepsilon-\mathrm{PL}$; (D) $0.5 \% \varepsilon$-PL; (E) $1 \%$ $\varepsilon$-PL P. gingivalis bacterial cells are reduced in number and display an irregular cell morphology because of membrane disruption.

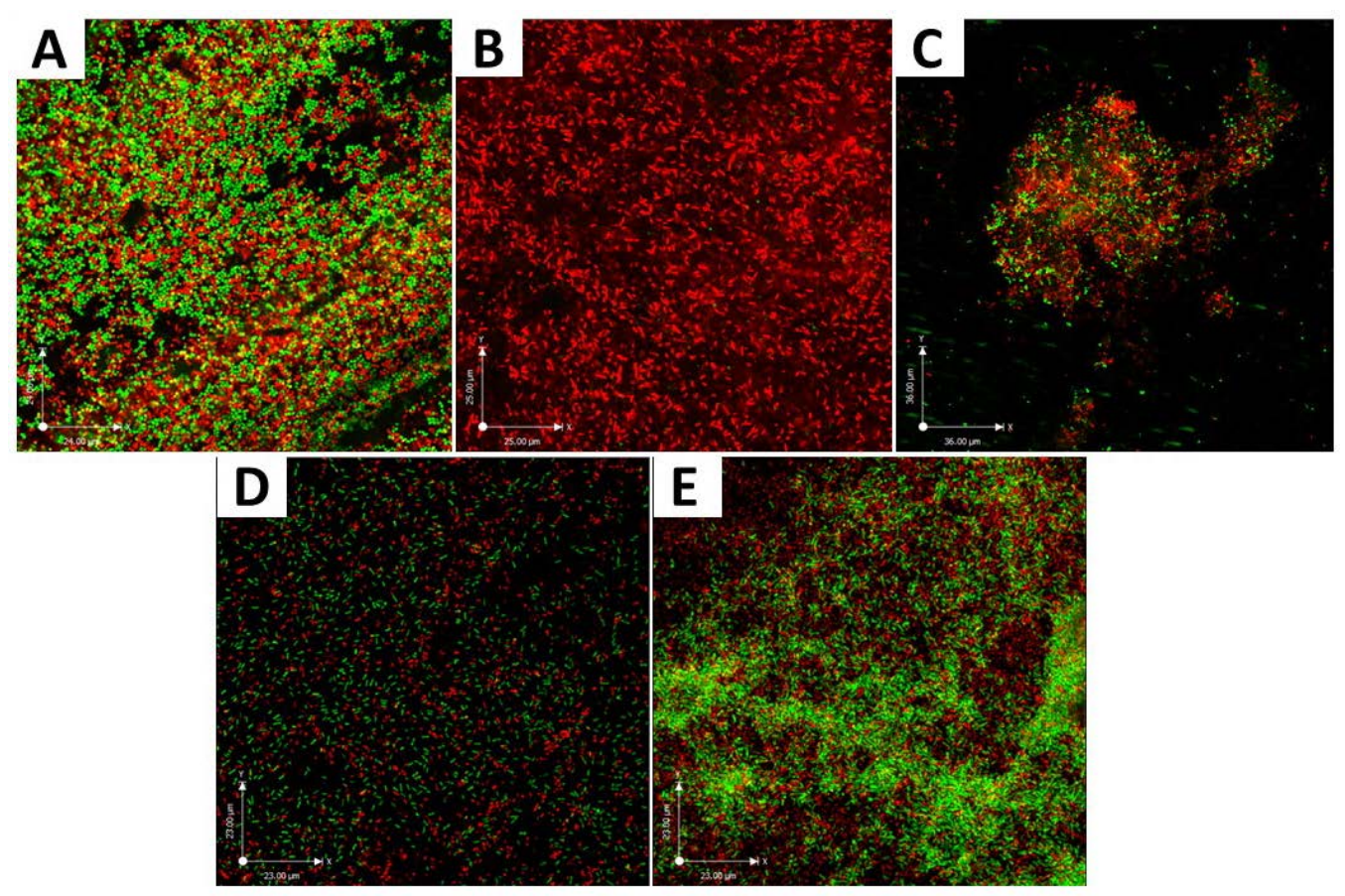

Figure 4. CLSM images of 7-day P. gingivalis biofilm on the dentin surface after application of different concentrations of $\varepsilon$-polylysine. Live bacterial cells are stained green (SYTO 9) and dead bacterial cells are stained red (propidium iodide). (A) control; (B) $0.125 \% \varepsilon$-PL; (C) $0.25 \% \varepsilon$-PL; (D) $0.5 \% \varepsilon-P L ;$ (E) $1 \% \varepsilon$-PL. 


\section{Discussion}

To overcome bacterial resistance to antibiotics, studies have investigated natural antibacterial peptides because their bactericidal ability and natural derivative lower the risk of developing resistant pathogens. We investigated $\varepsilon$-polylysine, known for its antibacterial effects as a food preservative. To our knowledge, few studies have examined the antibacterial effect of $\varepsilon$-polylysine against oral pathogens. The present in vitro study investigated the antibacterial effect of $\varepsilon$-polylysine against oral pathogens associated with periodontitis and dental caries, P. gingivalis and S. mutans. The results demonstrated that $\varepsilon$-polylysine had satisfactory antibacterial effects against the tested organisms.

We observed a significant reduction in $P$. gingivalis growth and the complete inhibition of $S$. mutans growth after $24 \mathrm{~h}$ of treatment with $\varepsilon$-polylysine. The SEM and CLSM results from the P. gingivalis biofilm dentin also demonstrated the damage caused by $\varepsilon$-polylysine to bacterial cell membranes. The antibacterial activity of $\varepsilon$-polylysine is attributed to the disturbance of cell membrane integrity leading to the formation of vesicles [29], oxidative stress by reactive oxygen species, and various gene expression effects [30]. The polypeptide has an affinity for bacterial membranes because of the electrostatic interaction between the negatively charged outer layer of the bacterium and the positively charged polypeptide. This attraction causes the microbes to strongly associate with these surfaces, leading to enhanced killing [29]. Moreover, the hydrophobicity of $P$. gingivalis plays an important role in its adhesion to different surfaces [31]. A previous study reported on the poly-l-lysine inhibitory effect on $P$. gingivalis fimbria binding to saliva coated hydroxyapatite [32].

Our results demonstrated that the susceptibility of microorganisms to $\varepsilon$-polylysine was dependant on $\varepsilon$-polylysine concentrations. The inhibitory effect of $\varepsilon$-polylysine against $S$. mutans increased with an increase in $\varepsilon$-polylysine concentration. At $\varepsilon$-polylysine concentrations of $0.5 \%$ and $1 \%, S$. mutans was completely inhibited after $12 \mathrm{~h}$, which continued until $24 \mathrm{~h}$, at which point the lower concentrations of $\varepsilon$-polylysine, $0.125 \%$ and $0.25 \%$, exhibited complete inhibition. Similar dose-dependent inhibitory qualities were observed in E. coli and S. aureus [33]. Dose-dependent inhibition was not observed in P. gingivalis in our study. In contrast to $S$. mutans, the lowest test concentration, $0.125 \%$, was significantly more efficient in $P$. gingivalis growth inhibition compared with the higher concentrations. Numerous microorganisms are inhibited by $\varepsilon$-polylysine, including yeast, fungi, and Gram-positive and Gram-negative organisms [34]. Researchers who have tested the same concentrations of $\varepsilon$-polylysine against Gram-positive and Gram-negative organisms reported that $\varepsilon$-polylysine was more efficient against Gram-negative organisms if the cell membrane surface charge was considered $[35,36]$. Gram-negative bacteria have a higher negative charge on cell surfaces than Gram-positive bacteria do. Therefore, the interaction and improved adherence with positively charged $\varepsilon$-polylysine may be associated with enhanced killing.

In this study, $\varepsilon$-polylysine demonstrated a higher bacterial killing effect when applied on dentin surfaces compared with bacterial killing in the liquid medium. The polypeptide binding affinity to bacterial cells was more pronounced during direct interaction with the bacterial cells compared with the bacterial suspension. Moreover, the growth medium was supplemented with various compounds that promote bacterial growth; thus, a greater bacterial killing of $\varepsilon$-polylysine may be observed when applied on the biofilm-dentin surface. Therefore, in clinical settings, the antibacterial effects are expected to be more effective.

\section{Conclusions}

The present study demonstrated that $\varepsilon$-polylysine had satisfactory antibacterial efficacy against P. gingivalis and S. mutans in the liquid culture medium and as an application on biofilm-dentin surfaces. The antibacterial effects were more pronounced against $S$. mutans. Organisms associated with periodontitis 
and caries may be resistant to antibiotics; thus, $\varepsilon$-polylysine can serve as an alternative for treating these pathogens.

Author Contributions: Investigation and data curation, S.D. and Y.-Y.L.; formal analysis, S.D. and I.W.; funding acquisition, Y.-H.P. and N.-C.T.; resources, I.W. and W.-J.C.; project administration, N.-C.T.; writing - original draft, S.D.; writing - review and editing, N.-C.T. All authors have read and agreed to the published version of the manuscript.

Funding: This research received no external funding.

Conflicts of Interest: The authors declare no conflict of interest.

\section{References}

1. Zijnge, V.; van Leeuwen, M.B.; Degener, J.E.; Abbas, F.; Thurnheer, T.; Gmur, R.; Harmsen, H.J. Oral biofilm architecture on natural teeth. PLoS ONE 2010, 5, e9321. [CrossRef]

2. Beikler, T.; Flemmig, T.F. Oral biofilm-associated diseases: Trends and implications for quality of life, systemic health and expenditures. Periodontol. 2000 2011, 55, 87-103. [CrossRef]

3. Hardie, J.M. Oral microbiology: Current concepts in the microbiology of dental caries and periodontal disease. Br. Dent. J. 1992, 172, 271-278. [CrossRef]

4. Ximenez-Fyvie, L.A.; Haffajee, A.D.; Socransky, S.S. Microbial composition of supra- and subgingival plaque in subjects with adult periodontitis. J. Clin. Periodontol. 2000, 27, 722-732. [CrossRef]

5. Calogiuri, G.; Di Leo, E.; Trautmann, A.; Nettis, E.; Ferrannini, A.; Vacca, A. Chlorhexidine hypersensitivity: A critical and updated review. J. Allergy Ther. 2013, 4, 10-4172.

6. Pemberton, M.; Gibson, J. Chlorhexidine and hypersensitivity reactions in dentistry. Br. Dent. J. 2012, 213, 547. [CrossRef]

7. Kulik, E.M.; Waltimo, T.; Weiger, R.; Schweizer, I.; Lenkeit, K.; Filipuzzi-Jenny, E.; Walter, C. Development of resistance of mutans streptococci and Porphyromonas gingivalis to chlorhexidine digluconate and amine fluoride/stannous fluoride-containing mouthrinses, in vitro. Clin. Oral Investig. 2015, 19, 1547-1553. [CrossRef]

8. Smiline, G.A.; Pandi, S.K.; Hariprasad, P.; Raguraman, R. A preliminary study on the screening of emerging drug resistance among the caries pathogens isolated from carious dentine. Indian J. Dent. Res. 2012, 23, 26. [CrossRef]

9. Gomi, K.; Yashima, A.; Nagano, T.; Kanazashi, M.; Maeda, N.; Arai, T. Effects of full-mouth scaling and root planing in conjunction with systemically administered azithromycin. J. Periodontol. 2007, 78, 422-429. [CrossRef]

10. Nakagawa, T.; Yamada, S.; Oosuka, Y.; Saito, A.; Hosaka, Y.; Ishikawa, T.; Okuda, K. Clinical and microbiological study of local minocycline delivery (Periocline) following scaling and root planing in recurrent periodontal pockets. Bull. Tokyo Dent. Coll. 1991, 32, 63-70.

11. Bonito, A.J.; Lux, L.; Lohr, K.N. Impact of local adjuncts to scaling and root planing in periodontal disease therapy: A systematic review. J. Periodontol. 2005, 76, 1227-1236. [CrossRef] [PubMed]

12. Rams, T.E.; Degener, J.E.; van Winkelhoff, A.J. Antibiotic Resistance in Human Chronic Periodontitis Microbiota. J. Periodontol. 2014, 85, 160-169. [CrossRef] [PubMed]

13. Ardila, C.M.; Granada, M.I.; Guzmán, I.C. Antibiotic resistance of subgingival species in chronic periodontitis patients. J. Periodontal Res. 2010, 45, 557-563. [CrossRef]

14. Sedlacek, M.J.; Walker, C. Antibiotic resistance in an in vitro subgingival biofilm model. Oral Microbiol. Immunol. 2007, 22, 333-339. [CrossRef]

15. Pepperney, A.; Chikindas, M.L. Antibacterial peptides: Opportunities for the prevention and treatment of dental caries. Probiotics Antimicrob. Proteins 2011, 3, 68. [CrossRef]

16. Shih, L.; Shen, M.-H.; Van, Y.-T. Microbial synthesis of poly ( $\varepsilon$-lysine) and its various applications. Bioresour. Technol. 2006, 97, 1148-1159. [CrossRef]

17. Shima, S.; Sakai, H. Polylysine produced by Streptomyces. Agric. Biol. Chem. 1977, 41, 1807-1809. [CrossRef]

18. Sayed, S.; Jardine, M. Antimicrobial biopolymers. In Advanced Functional Materials; John Wiley \& Sons Inc.: Hoboken, NJ, USA, 2015; pp. 493-533. 
19. Shukla, S.C.; Singh, A.; Pandey, A.K.; Mishra, A. Review on production and medical applications of $\varepsilon$-polylysine. Biochem. Eng. J. 2012, 65, 70-81. [CrossRef]

20. Wang, R.; Li, J.; Chen, W.; Xu, T.; Yun, S.; Xu, Z.; Xu, Z.; Sato, T.; Chi, B.; Xu, H. A Biomimetic Mussel-Inspired $\varepsilon$-Poly-l-lysine Hydrogel with Robust Tissue-Anchor and Anti-Infection Capacity. Adv. Funct. Mater. 2017, 27, 1604894. [CrossRef]

21. Gao, C.; Yan, T.; Du, J.; He, F.; Luo, H.; Wan, Y. Introduction of broad spectrum antibacterial properties to bacterial cellulose nanofibers via immobilising E-polylysine nanocoatings. Food Hydrocoll. 2014, 36, 204-211. [CrossRef]

22. Kazemzadeh-Narbat, M.; Kindrachuk, J.; Duan, K.; Jenssen, H.; Hancock, R.E.; Wang, R. Antimicrobial peptides on calcium phosphate-coated titanium for the prevention of implant-associated infections. Biomaterials 2010, 31, 9519-9526. [CrossRef] [PubMed]

23. Panpisut, P.; Liaqat, S.; Zacharaki, E.; Xia, W.; Petridis, H.; Young, A.M. Dental composites with calcium/strontium phosphates and polylysine. PLoS ONE 2016, 11, e0164653. [CrossRef]

24. Kangwankai, K.; Sani, S.; Panpisut, P.; Xia, W.; Ashley, P.; Petridis, H.; Young, A.M. Monomer conversion, dimensional stability, strength, modulus, surface apatite precipitation and wear of novel, reactive calcium phosphate and polylysine-containing dental composites. PLoS ONE 2017, 12, e0187757. [CrossRef]

25. Xie, S.-X.; Boone, K.; VanOosten, S.K.; Yuca, E.; Song, L.; Ge, X.; Ye, Q.; Spencer, P.; Tamerler, C. Peptide Mediated Antimicrobial Dental Adhesive System. Appl. Sci. 2019, 9, 557. [CrossRef]

26. Zhang, Y.; Wang, F.; Huang, Q.; Patil, A.B.; Hu, J.; Fan, L.; Yang, Y.; Duan, H.; Dong, X.; Lin, C. Layer-by-layer immobilizing of polydopamine-assisted $\varepsilon$-polylysine and gum Arabic on titanium: Tailoring of antibacterial and osteogenic properties. Mater. Sci. Eng. C 2020, 110, 110690. [CrossRef] [PubMed]

27. Feldman, M.; Sionov, R.; Smoum, R.; Mechoulam, R.; Ginsburg, I.; Steinberg, D. Comparative Evaluation of Combinatory Interaction between Endocannabinoid System Compounds and Poly-L-lysine against Streptococcus mutans Growth and Biofilm Formation. BioMed Res. Int. 2020, 2020, 7258380. [CrossRef]

28. Najjar, M.B.; Kashtanov, D.; Chikindas, M.L. Natural antimicrobials $\varepsilon$-poly-l-lysine and Nisin A for control of oral microflora. Probiotics Antimicrob. Proteins 2009, 1, 143. [CrossRef] [PubMed]

29. Hyldgaard, M.; Mygind, T.; Vad, B.S.; Stenvang, M.; Otzen, D.E.; Meyer, R.L. The antimicrobial mechanism of action of epsilon-poly-1-lysine. Appl. Environ. Microbiol. 2014, 80, 7758-7770. [CrossRef]

30. Ye, R.; Xu, H.; Wan, C.; Peng, S.; Wang, L.; Xu, H.; Aguilar, Z.P.; Xiong, Y.; Zeng, Z.; Wei, H. Antibacterial activity and mechanism of action of $\varepsilon$-poly-L-lysine. Biochem. Biophys. Res. Commun. 2013, 439, 148-153. [CrossRef]

31. Naito, Y.; Tohda, H.; Okuda, K.; Takazoe, I. Adherence and hydrophobicity of invasive and noninvasive strains of Porphyromonas gingivalis. Oral Microbiol. Immunol. 1993, 8, 195-202. [CrossRef]

32. Lee, J.; Sojar, H.T.; Bedi, G.S.; Genco, R.J. Synthetic peptides analogous to the fimbrillin sequence inhibit adherence of Porphyromonas gingivalis. Infect. Immun. 1992, 60, 1662-1670. [CrossRef]

33. Li, Y.-Q.; Han, Q.; Feng, J.-L.; Tian, W.-L.; Mo, H.-Z. Antibacterial characteristics and mechanisms of $\varepsilon$-poly-lysine against Escherichia coli and Staphylococcus aureus. Food Control 2014, 43, 22-27. [CrossRef]

34. Zhou, C.; Li, P.; Qi, X.; Sharif, A.R.; Poon, Y.F.; Cao, Y.; Chang, M.W.; Leong, S.S.; Chan-Park, M.B. A photopolymerized antimicrobial hydrogel coating derived from epsilon-poly-L-lysine. Biomaterials 2011, 32, 2704-2712. [CrossRef]

35. Chang, S.S.; Lu, W.Y.; Park, S.H.; Kang, D.H. Control of foodborne pathogens on ready-to-eat roast beef slurry by epsilon-polylysine. Int. J. Food Microbiol. 2010, 141, 236-241. [CrossRef] [PubMed]

36. Gottenbos, B.; Grijpma, D.W.; van der Mei, H.C.; Feijen, J.; Busscher, H.J. Antimicrobial effects of positively charged surfaces on adhering Gram-positive and Gram-negative bacteria. J. Antimicrob. Chemother. 2001, 48, 7-13. [CrossRef]

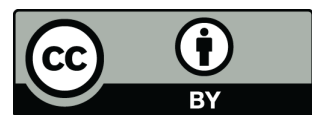

(C) 2020 by the authors. Licensee MDPI, Basel, Switzerland. This article is an open access article distributed under the terms and conditions of the Creative Commons Attribution (CC BY) license (http://creativecommons.org/licenses/by/4.0/). 